\title{
Delimitasi Batas Pengelolaan Laut menurut Permendagri Nomor 141 Tahun 2017 (Studi Kasus: Provinsi Maluku Utara)
}

\author{
Delimitation of Marine Management based on Permendagri 141 Year 2017 \\ (Case Study: North Maluku Province)
}

\author{
Haris Hakim Prasetyo ${ }^{1}$, Khomsin*2, Danar Guruh Pratomo ${ }^{3}$ \\ ${ }^{1,2,3}$ Departemen Teknik Geomatika, FTSLK-ITS, Kampus ITS Sukolilo, Surabaya, 60111, Indonesia \\ *Korespondensi penulis: khomsin@geodesy.its.ac.id
}

Diterima : 14082020; Diperbaiki : 04092020; Disetujui : 09092020; Dipublikasi : 13112020

\begin{abstract}
Abstrak: Terbentuknya Peraturan Menteri Dalam Negeri Republik Indonesia Nomor 141 Tahun 2017 tentang Penegasan Batas Daerah yang mengacu kepada Undang - Undang Nomor 23 Tahun 2014. Sehinga ketentuan tersebut merupakan pedoman dalam penentuan delimitasi batas. Secara geografis Provinsi Maluku Utara memiliki pulau pulau yang saling berdekatan dengan berbagai ukuran tipe, dengan mengesampingkan faktor sosial budaya Provinsi Maluku Utara dapat dikatakan sebagai provinsi yang berciri kepulauan. Provinsi Maluku Utara berbatasan langsung dengan Provinsi Papua Barat jarak antara kedua Provinsi tersebut kurang dari 24 mil maka dari itu perlu diadakan delimitasi batas wilayah pengelolaan laut. Penelitian ini bertujuan untuk menentukan luas wilayah pengelolaan laut dan batas wilayah pengelolaan laut Provinsi Maluku Utara. Dalam penelitian ada dua baseline yang digunakan, yaitu Normal Baseline menurut Permendagri No.141/2017 dan Archipelagic Baseline berdasarkan Rancangan Undang Undang (RUU) tentang Percepatan Pembangunan Daerah Kepulauan. Hal ini yang menyebabkan perbedaan penarikan batas pengelolaan laut pada kedua Provinsi yang mengakibatkan perubahan pada luas wilayah pengelolaan laut. Perubahan pada baseline mengakibatkan perubahan point - point yang digunakan dalam pembentukan thieseen polygon. Hal ini yang menyebabkan perbedaan penarikan batas pengelolaan laut pada kedua Provinsi. Perbedaan kedua baseline ini akan menentukan wilayah pengelolaan laut. Luas wilayah pengelolaan laut Provinsi Maluku Utara dengan menggunakan normal baseline sebesar 88.743,06 km², sedangkan dengan menggunakan archipelagic baseline berdasarkan RUU sebesar $152.958,92 \mathrm{~km}^{2}$. Penelitian ini diharapkan menjadi referensi terkait penegasan kewenangan pengelolaan laut daerah bagi pemerintah daerah maupun instansi yang berwenang dan memberikan alternatif penegasan batas daerah di Provinsi Maluku Utara.
\end{abstract}

Copyright $\odot 2020$ Geoid. All rights reserved.

\begin{abstract}
Establishment Permendagri No. 141 year 2017 on the affirmation of regional boundaries referring to Undang - Undang No. 23 year 2014. These provisions are guidelines in determining boundary delimitation. Geographically, the province of North Maluku has islands that are adjacent to various types of type, by putting aside the socio-cultural factors of North Maluku Province can be said to be an archipelago-characterized province. North Maluku Province is directly adjacent to West Papua province the distance between the two provinces is less than 24 miles hence it is necessary to place the delimitation of the boundary of the Sea management area. This research aims to determine the area of marine management and boundaries of the Sea management region of North Maluku province. In this study, there are two baselines used, namely normal baseline according to Permendagri No.141/2017 and archipelagic baseline according to Rancangan Undang - Undang (RUU). Changes to the baseline result in pointpoint changes used in the Thieseen polygon formation. This led to the difference in the withdrawal of sea management boundaries in both provinces which resulted in a change in the area of marine management. These two baseline differences will determine the area of marine management. The area of marine management in North Maluku Province using the normal baseline is $88,743.06 \mathrm{~km}^{2}$ while using the archipelagic baseline based on RUU is $152,958.92 \mathrm{~km}^{2}$. This research is expected to be a reference to the affirmation of regional marine Management Authority for local government and authorized agencies and provide an alternative to an affirmation of regional boundaries in North Maluku province.
\end{abstract}

Kata kunci: Delimitasi Batas; Maluku Utara; Wilayah Pengelolaan Laut; Normal Baseline; Archipelagic Baseline 


\section{Pendahuluan}

Lahirnya Peraturan Menteri Dalam Negeri Republik Indonesia Nomor 141 Tahun 2017 Tentang Penegasan Batas Daerah dilatar belakangi karena Peraturan Menteri Dalam Negeri Republik Indonesia Nomor 76 Tahun 2012 Tentang Pedoman Penegasan Batas Daerah dianggap tidak sesuai dengan perkembangan keadaan, ketatanegaraan, dan tuntutan penyelenggaraan otonomi daerah sehingga perlu diganti dengan peraturan menteri yang baru (Permendagri No. 141 2017).

Pada Permendagri kurang efektif dalam hal pengawasan dan pembangunan pada daerah kepulauan, sehingga munculah Rancangan Undang - Undang (RUU) Republik Indonesia tentang Percepatan Pembangunan Daerah Kepulauan. Rancangan tersebut dibuat mengacu sebagian kepada Hukum Laut Internasional United Nations Convention on The Law of The Sea (UNCLOS) Bab IV tentang Negara Kepulauan. Salah satu peraturannya yaitu dapat menarik garis pangkal dengan jarak maksimum tidak melebihi 100 mil laut, kecuali hingga 3 (tiga) persen dari jumlah garis itu dapat melebihi kepanjangan tersebut, hingga pada suatu kepanjangan maksimum 125 (seratus dua puluh lima) mil laut (UNCLOS, 1982).

Provinsi Maluku Utara memiliki pulau - pulau yang saling berdekatan dengan berbagai ukuran tipe, dengan mengesampingkan faktor sosial budaya Provinsi Maluku Utara dapat dikatakan sebagai provinsi yang berciri kepulauan. Provinsi Maluku Utara berbatasan langsung dengan Provinsi Papua Barat jarak antara kedua Provinsi tersebut kurang dari 24 mil maka dari itu perlu diadakan delimitasi batas wilayah pengelolaan laut. Ini berarti bahwa masing-masing Provinsi tidak dapat mengklaim 12 mil laut tanpa menggangu klaim Provinsi lainnya, sehingga perlu dilakukan delimitasi batas wilayah maritim antara Provinsi yang berdampingan maupun bersebrangan (Adnyana dkk, 2006).

Berdasarkan pada kondisi tersebut, pada penelitian ini dilakukan dua macam penentuan penarikan garis pangkal (baseline), penentuan garis pangkal tersebut diatur dalam Rancangan Undang - Undang tentang Percepatan Pembangunan Daerah Kepulauan yaitu garis pangkal kepulauan (archipelagic baseline) dan diatur dalam Permendagri No. 141 Tahun 2017 yaitu garis pangkal normal (normal baseline). Garis pangkal tersebut yang akan dijadikan acuan untuk menarik wilayah pengelolaan sejauh 12 mil laut. Hasil dari delimitasi batas wilayah, akan menghasilkan luasan lautan dan batas maritim antara Provinsi Maluku Utara dan sekitarnya.

\section{Metode}

Penelitian ini terletak di Provinsi Maluku Utara yang secara geografis terletak pada koordinat $3^{\circ} 40^{\prime}$ LS- $3^{\circ} 0$ ' LU dan $123^{\circ}$ 50'-129 $50^{\circ}$ ' BT. Lokasi penelitian ditampilkan pada Gambar 1, dengan polygon merah adalah Batas Administrasi Provinsi Maluku Utara.

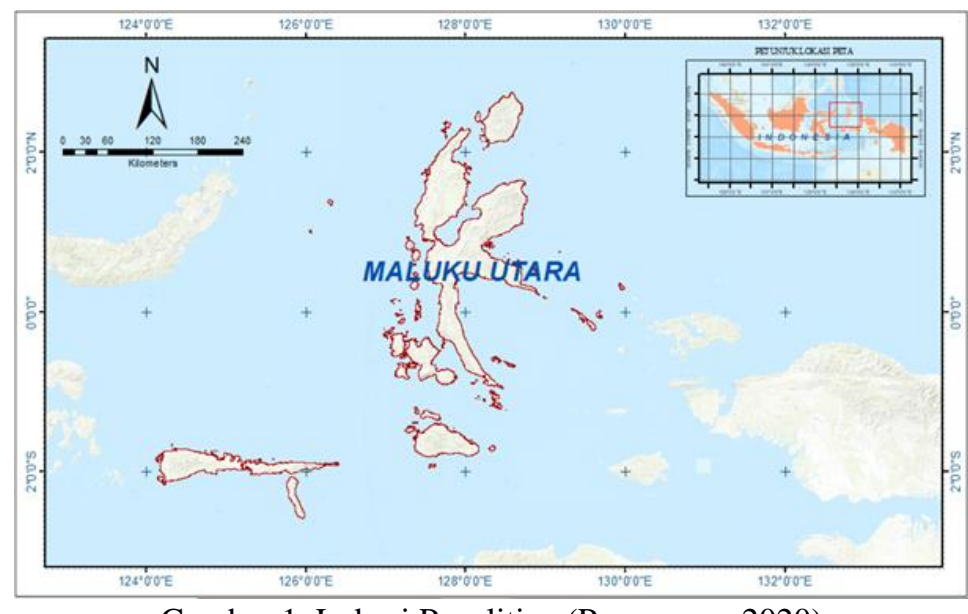

Gambar 1. Lokasi Penelitian (Pengarang, 2020) 
Peralatan yang digunakan untuk mendukung penelitian ini meliputi perangkat lunak (software). Perangkat lunak (software) yang digunakan yaitu perangkat lunak pengolahan data spasial dan perangkat lunak pengolah kata.

Adapun data yang digunakan untuk mendukung penelitian ini meliputi Batas Administrasi Provinsi Maluku Utara (polygon) dan Garis Pantai Kebijakan Satu Peta (polyline), kedua data tersebut didapatkan dari Badan Informasi Geospasial (BIG). Batas Administrasi digunakan untuk mengetahui wilayah yang bersengketa pada Provinsi Maluku Utara. Sengketa yang disebabkan adanya salin klaim terhadap alokasi pulau maka garis pantai tidak digunakan dalam kontruksi penarikan garis wilayah pengelolaan laut. Garis Pantai Kebijakan Satu Peta (Garpan KSP) garis pantai yang dibuat sesuai dengan acuan terbaru pada UU. No. 23 Tahun 2014, Garpan KSP digunakan untuk penarikan garis wilayah pengelolaan laut.

Tahap awal dalam penelitian ini adalah pemilihan dari daerah yang bersengketa, daerah yang disengketakan diabaikan dan tidak diproses. Setelah itu pemilihan data yang akan diekspor di garis pantai, data yang akan diekspor adalah data garis pantai provinsi Maluku Utara, dan garis pantai yang digunakan mengacu pada pasang tertinggi, disajikan pada Gambar 2.

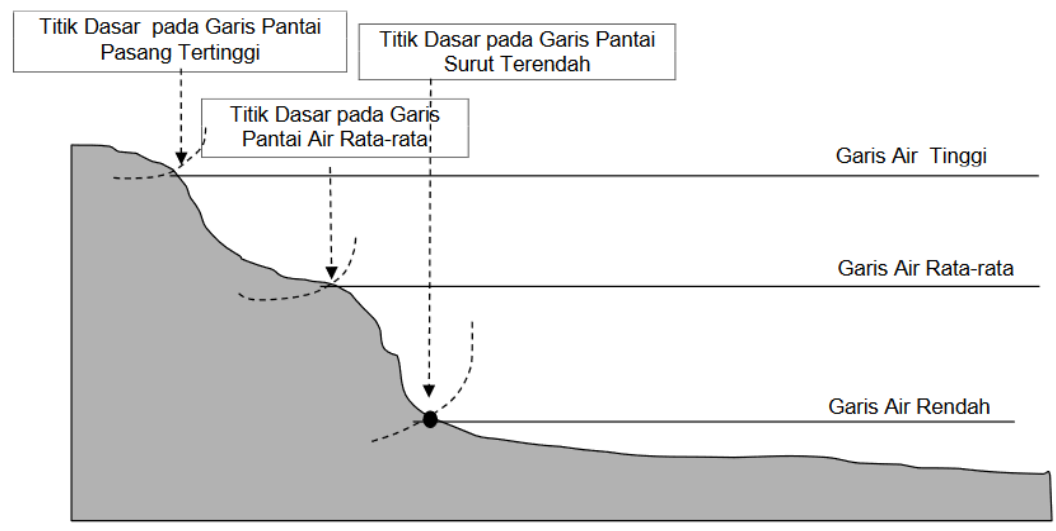

Gambar 2. Titik Dasar dan Garis Pantai (Permendagri No.141 2017)

Tahap kedua penyamaan datum dan sitem proyeksi, pada penelitian ini datum horisontal yang digunakan yaitu WGS-84 dengan sistem proyeksi Lambert Cylindrical Equal Area yang merupakan proyeksi yang mempertahankan luasan wilayah dengan benar dan teliti (Amrillah dkk 2017). Proyeksi ini menghasilkan garis lintang dan bujur yang lurus dengan spasi antar garis lintang yang seragam namum spasi antar garis bujur tidak sama. Dapat dikelompokkkan menjadi Normal, Transversal, serta Oblique, sesuai dengan posisi sumbu proyeksinya (Tjahyadi, 2010). Dapat dilihat dari Gambar 3, dimana lingkaran sempurna yang ditampilkan ketika proyeksi ini digunakan pada ekuator yang artinya daerah equator tidak ada distorsi dalam pengaruh luasan, tetapi semakin menjauhi ekuator lingkaran semakin melonjong yang artinya terjadi distorsi.

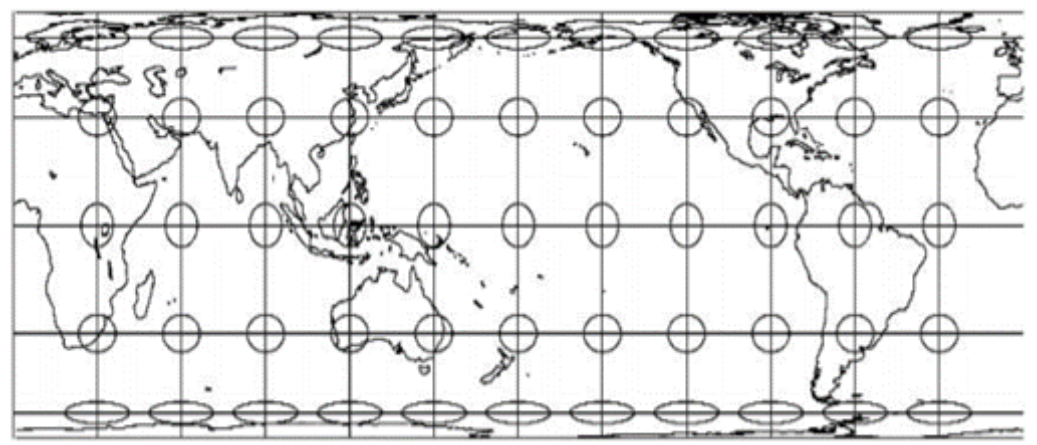

Gambar 3. Proyeksi Lambert Clindrical Equal Area (Grafarend dan Krumm, 2006) 
Selanjutnya yaitu pembuatan garis pangkal, pembuatan garis pangkal mengacu pada Permendagri No. 141 Tahun 2017 (normal baseline) dan pembuatan garis pangkal mengacu pada RUU (archipelagic baseline). Pada Archipelagic Baseline menggunakan Aggregate Polygons, digambarkan pada Gambar 4, yaitu untuk membuat boundary dengan batas maksimal segmen 100 nautical mil. Selanjutnya dilakukan pengecekan Aggregate Polygons berdasarkan pulau terluar.
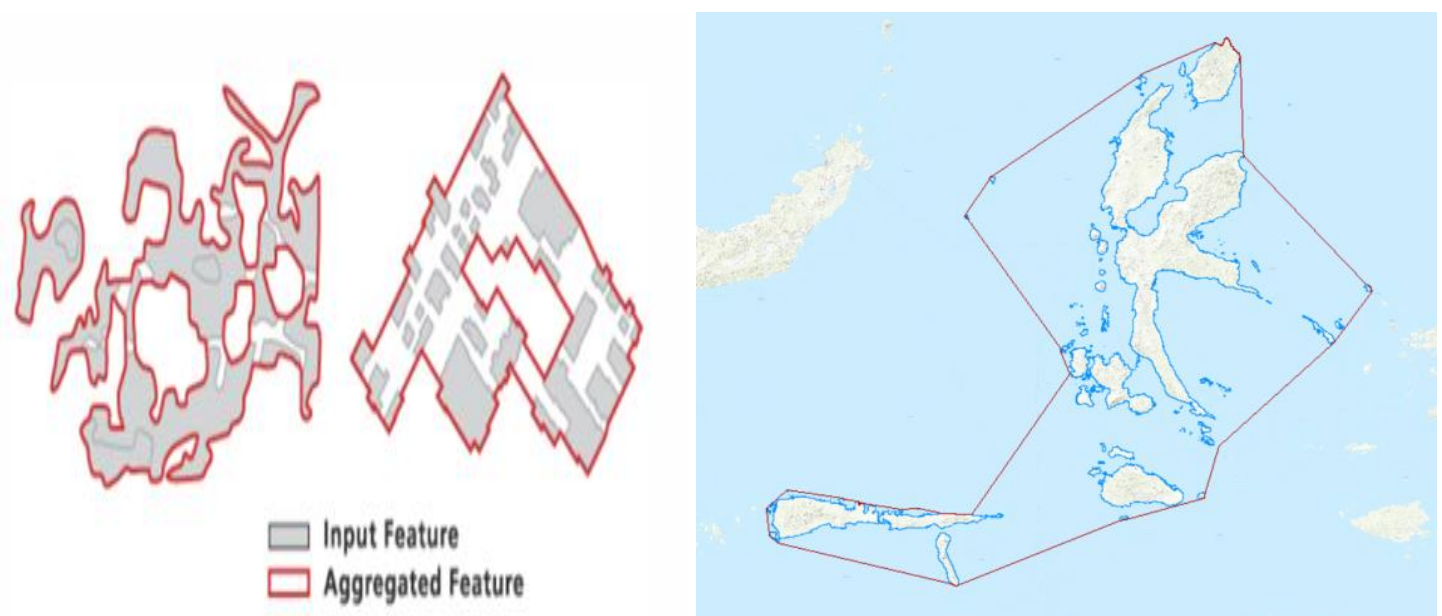

Gambar 4. Hasil Pengolahan Menggunakan Agregate Polygon (Esri 2016)

Setelah didapatkan hasil Agregate Polygons, selanjutnya mengonversikan garis pantai menggunakan normal baseline dan archipelagic baseline kedalam bentuk point dan polygon. Bentuk point digunakan untuk pembuatan Thieseen Polygon, dapat dilihat pada Gambar 5. Sedangakan hasil konversi yang berbentuk polygon untuk pembuatan buffer sejauh 12 nautical mil. Penggambaran garis sama jarak dan garis tengah (median line) menggunakan pendekatan Thiessen Polygon.

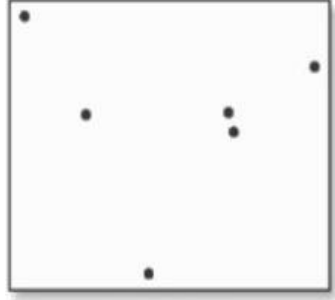

INPUT

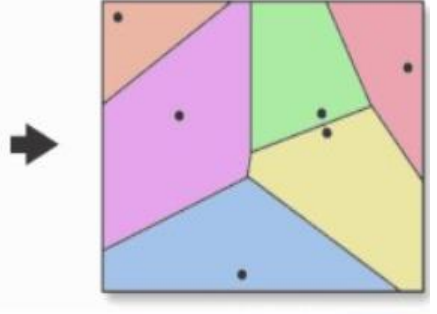

OUTPUT

Gambar 5. Metode Thiessen Polygon (Esri, 2016)

Selanjutnya menentukan batas wilayah yang saling berpotongan dengan prinsip median line menggunakan pendekatan Thiessen Polygon. Dalam hal ini penentuan batas antara Provinsi Maluku Utara dengan Provinsi Papua Barat.

\section{Hasil dan Pembahasan}

Wilayah Pengelolaan Laut Provinsi Maluku Utara dengan Provinsi Provinsi Papua Barat. Penarikan garis untuk menentukan batas wilayah sejauh 12 mil laut berdasarkan Permendagri No.141 tahun (normal baseline) dan aturan RUU tentang Percepatan Pembangunan Daerah Kepulauan (achipelagic baseline).

Luas wilayah pengelolaan laut berdasarkan Permendagri No.141 tahun (normal baseline) Provinsi Maluku Utara sebesar 88.743,06 km². Gambar 6 merupakan luas wilayah pengelolaan laut Provinsi Maluku Utara menggunakan normal baseline. Polyline merah menunjukkan penarikan baseline menggunakan normal baseline, penarikan garis untuk menentukan batas wilayah sejauh 12 mil yang ditampilkan pada polygon berwarna ungu menunjukkan batas pengelolaan wilayah laut Provinsi Maluku Utara. 


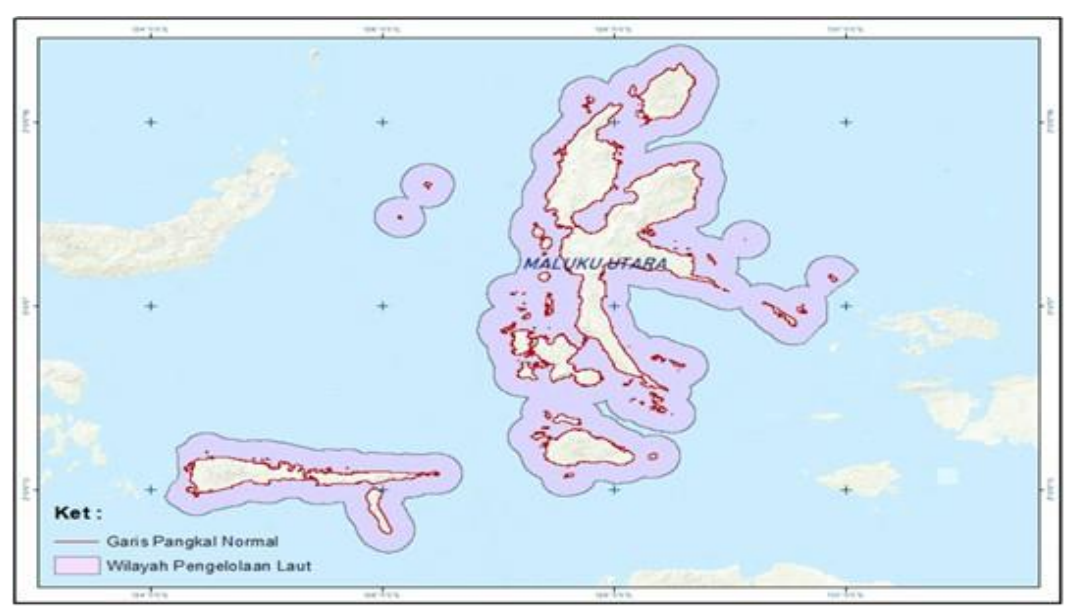

Gambar 6. Wilayah Pengelolaan Laut Menggunakan Normal Baseline (Pengarang, 2020)

Luas Wilayah Pengelolaan Laut berdasarkan RUU tentang Percepatan Pembangunan Daerah Kepulauan (archipelagic baseline) Provinsi Maluku Utara sebesar 152.958,92 $\mathrm{km}^{2}$. Gambar 7 merupakan luas wilayah pengelolaan laut Provinsi Maluku Utara menggunakan archipelagic baseline. Polyline merah menunjukkan penarikan baseline menggunakan archipelagic baseline, penarikan garis untuk menentukan batas wilayah sejauh 12 mil yang ditampilkan pada polygon berwarna ungu menunjukkan batas pengelolaan wilayah laut Provinsi Maluku Utara.

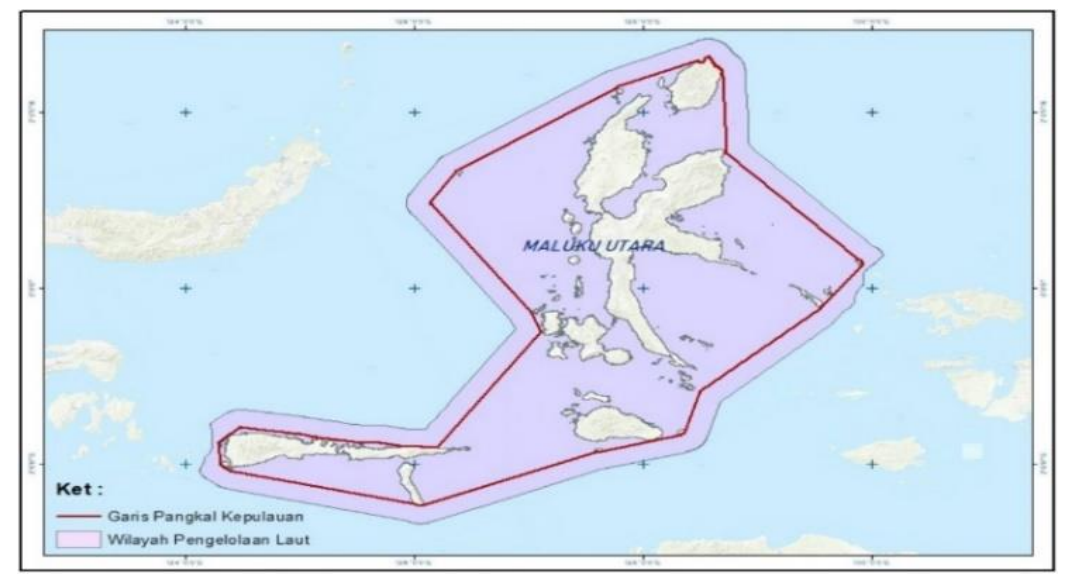

Gambar 7. Wilayah Pengelolaan Laut Menggunakan Archipelagic Baseline (Pengarang, 2020)

Luasan yang dihasilkan dari kedua metode normal baseline dan archipelagic baseline ditunjukkan pada Tabel 1 sebagai berikut:

Tabel 1. Luas Wilayah Pengelolaan Laut Provinsi Maluku Utara (Pengarang, 2020)

\begin{tabular}{cccc}
\hline \multirow{2}{*}{ No. } & \multirow{2}{*}{ Provinsi } & \multicolumn{2}{c}{ Luasan Laut $\left(\mathrm{Km}^{2}\right)$} \\
\cline { 3 - 4 } & & Normal baseline & Archipelagic baseline \\
\hline 1 & Maluku Utara & $88.743,06$ & $152.958,92$ \\
\hline
\end{tabular}

Dari Gambar 6 dan Gambar 7 dapat dilihat perbedaan pada batas wilayah pengelolaan laut pada bagian barat dan bagian timur Provinsi Maluku Utara. Perbedaan batas antara Provinsi Maluku Utara menggunakan normal baseline dan archipelagic baseline dipengaruhi oleh baseline yang digunakan berbeda. Perbedaan tersebut dapat dilihat pada Gambar 8 dengan normal baseline dan Gambar 9 dengan archipelagic baseline untuk batas antara Provinsi Maluku Utara dan Provinsi Papua Barat. 


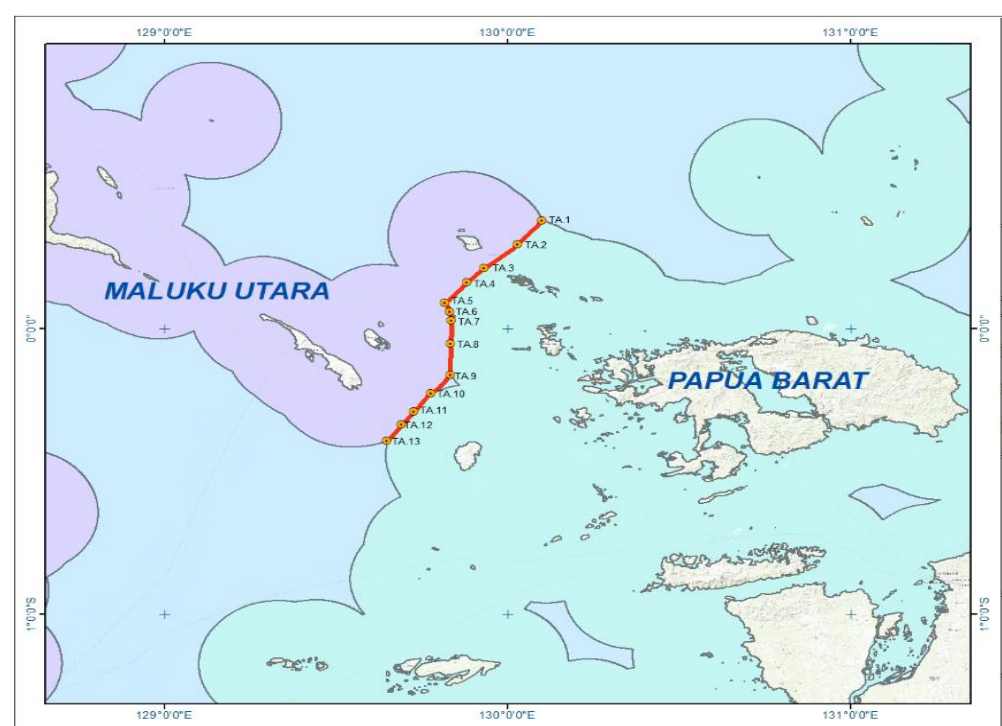

Gambar 8. Batas Wilayah Provinsi Maluku Utara dan Provinsi Papua Barat dengan Normal Baseline (Pengarang, 2020)

Berikut Koordinat Gambar 8 Batas Wilayah Provinsi Maluku Utara (normal baseline) dengan Provinsi Papua Barat (normal baseline), dapat dilihat pada Tabel 2

Tabel 2. Koordinat Batas Wilayah Provinsi Maluku Utara dan Provinsi Papua Barat dengan Normal Baseline (Pengarang, 2020)

\begin{tabular}{cccccc}
\hline Nama & Lintang & Bujur & Nama & Lintang & Bujur \\
\hline TA.1 & 0,377305 & 130,103202 & TA.8 & $-0,052475$ & 129,835565 \\
\hline TA.2 & 0,295877 & 130,030795 & TA.9 & $-0,161652$ & 129,835613 \\
\hline TA.3 & 0,211744 & 129,932837 & TA.10 & $-0,226744$ & 129,777873 \\
\hline TA.4 & 0,160474 & 129,883353 & TA.11 & $-0,290087$ & 129,728506 \\
\hline TA.5 & 0,088939 & 129,819516 & TA.12 & $-0,337177$ & 129,692243 \\
\hline TA.6 & 0,060069 & 129,833569 & TA.13 & $-0,392912$ & 129,650176 \\
\hline TA.7 & 0,028085 & 129,839229 & & & \\
\hline
\end{tabular}

Dari Tabel 2 dapat dilihat batas wilayah Provinsi Maluku Utara dengan Provinsi Papua Barat terdapat 13 Titik Acuan dengan koordinat menggunakan Datum WGS-84.

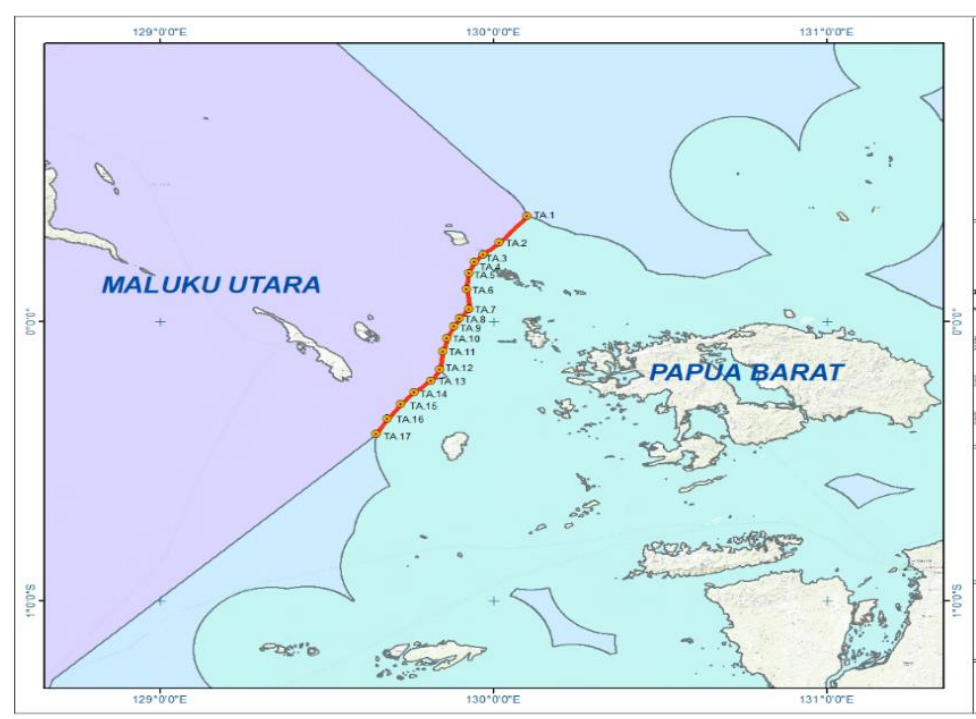

Gambar 9. Batas Wilayah Provinsi Maluku Utara dengan Archipelagic Baseline dan Provinsi Papua Barat dengan Normal Baseline (Pengarang, 2020) 
Berikut Koordinat Gambar 9 Batas Wilayah Provinsi Maluku Utara (normal baseline) dengan Provinsi Papua Barat (normal baseline), dapat dilihat pada Tabel 3.

Tabel 3. Koordinat Batas Wilayah Provinsi Maluku Utara dengan Archipelagic Baseline dan Provinsi Papua Barat dengan Normal Baseline (Pengarang, 2020)

\begin{tabular}{cccccc}
\hline Nama & Lintang & Bujur & Nama & Lintang & Bujur \\
\hline TA.1 & 0,37771 & 130,101955 & TA.10 & $-0,060214$ & 129,862456 \\
\hline TA.2 & 0,282724 & 130,019636 & TA.11 & $-0,107416$ & 129,849112 \\
\hline TA.3 & 0,240896 & 129,970279 & TA.12 & $-0,170867$ & 129,841299 \\
\hline TA.4 & 0,21284 & 129,945952 & TA.13 & $-0,211347$ & 129,813159 \\
\hline TA.5 & 0,174127 & 129,92796 & TA.14 & $-0,25298$ & 129,763898 \\
\hline TA.6 & 0,116457 & 129,921646 & TA.15 & $-0,296399$ & 129,7239 \\
\hline TA.7 & 0,045719 & 129,929094 & TA.16 & $-0,347857$ & 129,684241 \\
\hline TA.8 & 0,010617 & 129,899401 & TA.17 & $-0,403539$ & 129,649017 \\
\hline TA.9 & $-0,016242$ & 129,88224 & & & \\
\hline
\end{tabular}

Dari Tabel 3 dapat dilihat batas wilayah Provinsi Maluku Utara dengan Provinsi Papua Barat terdapat 17 Titik Acuan dengan koordinat menggunakan Datum WGS-84. Dengan koordinat dan titik yang berbeda.

Perubahan pada baseline mengakibatkan perubahan point - point yang digunakan dalam pembentukan thieseen polygon. Hal ini yang menyebabkan perbedaan penarikan batas pengelolaan laut pada kedua Provinsi yang mengakibatkan perubahan pada luas wilayah pengelolaan laut. Perbedaan penarikan median line antara Provinsi Maluku Utara dan Provinsi Papua Barat digambarkan pada Gambar 10.
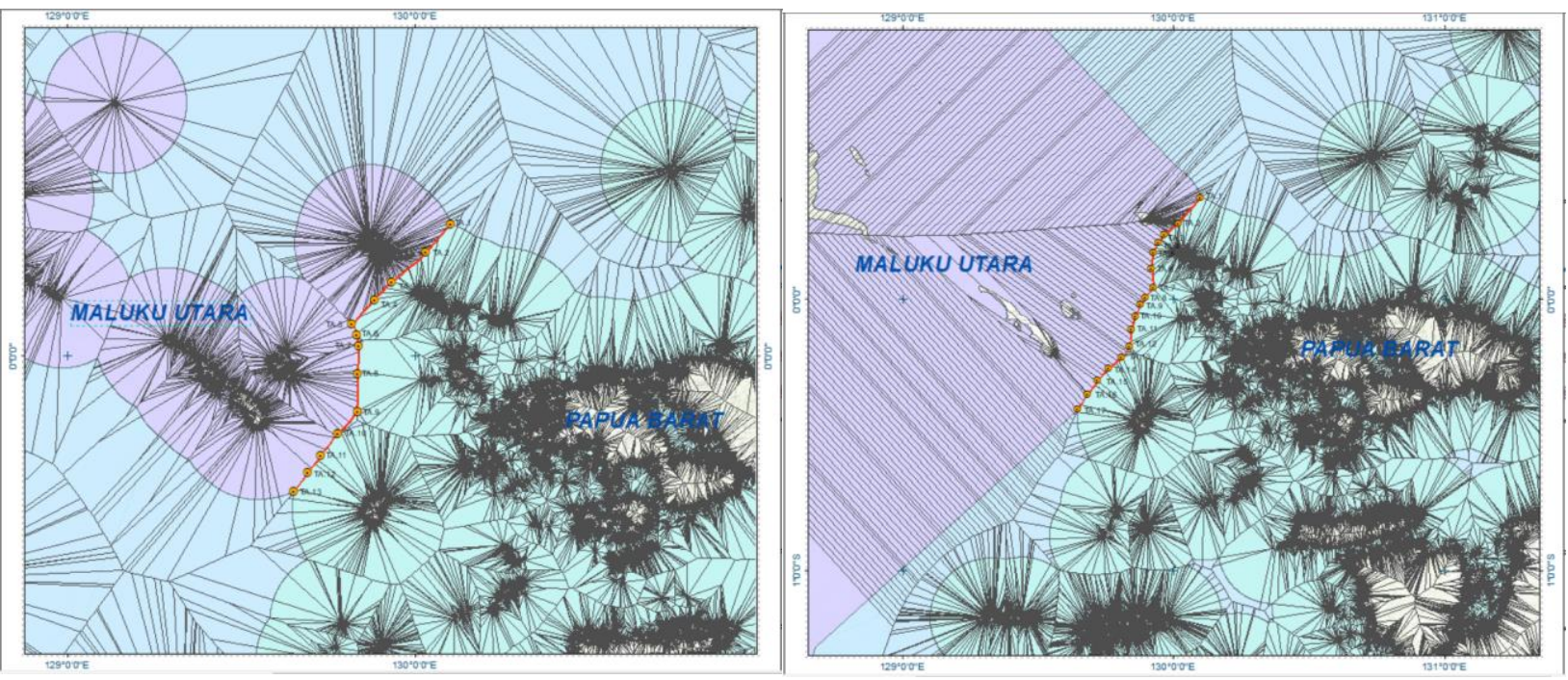

Gambar 10. Metode Thiessen Polygon untuk Pendekatan Median Line

Pada Gambar 10 menggambarkan perubahan pada baseline yang digunakan dalam penarikan garis tengah (median line) antara normal baseline dan archipelagic baseline. Dalam menentukan median line pada area yang jaraknya kurang dari 24 mil laut, dilakukan export dari bentuk polygon pada baseline menjadi point, kerapatan point mempengaruhi bentuk dari thiessen polygon. Point tersebut akan digunakan untuk pembuatan thiessen polygon (kerangka polygon hitam). Median line (polyline merah) adalah penegasan dari hasil thiessen polygon yang terbentuk. 


\section{Kesimpulan}

Pada penelitian ini, didapatkan luas wilayah pengelolaan laut Provinsi Maluku Utara dengan menggunakan normal baseline berdasarkan Permendagri no. 141 tahun 2017 sebesar 88.743,06 km², sedangkan dengan menggunakan archipelagic baseline berdasarkan RUU tentang Percepatan Pembangunan Daerah Kepulauan sebesar $152.958,92 \mathrm{~km}^{2}$.

Batas wilayah antara Provinsi Maluku Utara dan Papua Barat dengan menggunakan normal baseline memiliki rentang dari 0,392912 LS - 0,377305 LU dan 129,650176 BT - 130,103202 BT. Sedangkan dengan menggunakan Archipelagic Baseline memiliki rentang dari 0,403539 LS - 0,37771 LU dan 129,649017 BT 130,101955 BT.

Dari hasil perbedaan baseline untuk delimitasi perbedaan batas wilayah antara Provinsi Maluku Utara dan Provinsi Papua Barat di dapatkan perubahan bentuk yang disebabkan oleh perubahan point - point yang digunakan dalam pembentukan thieseen polygon. Hal ini yang menyebabkan perbedaan penarikan batas pengelolaan laut pada kedua Provinsi.

\section{Ucapan Terimakasih}

Penulis mengucapkan terima kasih kepada Badan Informasi Geospasial yang telah menyediakan data dan menyediakan tempat untuk pemrosesan data.

\section{Daftar Pustaka}

Kementerian Dalam Negeri. 2017. Peraturan Menteri Dalam Negeri Republik Indonesia Nomor 141 Tahun 2017 Tentang Penegasan Batas Daerah. Jakarta.

Secretary General of The United Nations. 1994. United Nations Convention on The Law of The Sea 1982. Montego Bay, Jamaika.

Adnyana, I Gede Pasek Sutrana dkk. 2006. Jurnal : Delimitasi Batas Maritim antara Provinsi Bali dan Provinsi Nusa Tenggara Barat:Sebuah Kajian Teknis, Yogyakarta : Jurusan Teknik Geodesi dan Geomatika Universitas Gajah Mada.

Amrillah, Dede dkk. 2017. Analisis Spasial Dalam Penentuan Daerah Provinsi Berciri Kepulauan. Bogor.

Tjahyadi, Arief. 2010. Sistem Proyeksi Peta. Bandung. Diakses pada tanggal 13 Maret 2020. https://www.slideshare.net/ lailiaidi/sistem-proyeksi-peta-3144291.

Grafarend, E. dan Krumm, F. 2006. Map Projections. Heidelberg: Springer.

Esri. 2016. AggregatePolygons. Diakses pada taggal 12 Maret 2020. https://desktop.arcgis.com/en/arcmap/10.3/tools/car tography-toolbox/aggregate-polygons.htm.

Banata. 2010. Poligon Thiessen. Diakses pada 20 Maret 2020.https://www.geo.web.id/2010/11/29/poligon-thiessen.

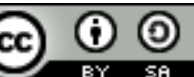

This article is licensed under a Creative Commons Attribution-ShareAlike 4.0 International License 